気管支鏡の基礎と呼吸器疾患に対する超音波の応用

高橋博人1

要旨一一気管支鏡の基礎 . 麻酔を中心に, $\mathrm{B}^{1+2} \mathrm{a}+\mathrm{b}$ への反転を用いた鉗子挿入法を解説した . 最近の話題 . P-260 による $\mathrm{B}^{1+2} \mathrm{a}+\mathrm{b}$ への挿入法，XBF-260F による気管内反転法を紹介した. 呼吸器疾患に対する超音波の応用. 超音波診 断は卓越した局所分解能を持ち，また血流等の機能診断が可能である.我々は肺癌等の呼吸器疾患の補助診断法として 積極的に応用してきたので，経気管超音波内視鏡 (TUS)，経食道超音波内視鏡下穿刺吸引法 (EUS-FNAB)，体表超音 波検査，術中超音波検査を中心に報告した．(肺癌．2005;45:75-78)

索引用語一一麻酔, 超音波検査, 経気管超音波内視鏡 (TUS), 経食道超音波内視鏡下穿刺吸引法 (EUS-FNAB)

\title{
Basic Aspects of a Bronchoscopy and Applications of Ultrasonography for Respiratory Disease
}

\author{
Hi roto Takahashi ${ }^{1}$
}

ABSTRACT — Basic aspects of bronchoscopy. This paper explains the anesthesia and insertion method of forceps with 180 degrees angulation to $\mathrm{B}^{1+2} \mathrm{a}+\mathrm{b}$. Recent topic in bronchoscopy. This paper explains the insertion method of forceps to $B^{1+2} a+b$ by P-260 and the endotracheal inversion method by XBF-260F. Applications of ultrasonography for respiratory disease. Ultrasonography shows prominent local resolution, and a functional diagnosis is possible by observation of blood flow. We applied this method to the diagnosis of lung cancer, and we discuss mainly trans-tracheal endoscopic ultrasonography (TUS), trans-esophageal endoscopic ultrasonography guided fine needle aspiration biopsy (EUS-FNAB), body surface ultrasonography and perioperative ultrasonography. (J L LC. 2005;45:75-78) KE Y WORDS — Anesthesia, Ultrasonography, Trans-tracheal endoscopic ultrasonography (TUS), Trans-esophageal endoscopic ultrasonography guided fine needle aspiration biopsy (EUS-F NAB)

\section{気管支鏡の基礎と最近の話題}

はじめに

気管支鏡は専門医数が少ないだけでなく内視鏡操作技 術にも施設間での格差がまだまだ大きい印象を持つ.気 管支鏡の基本として，麻酔を中心に, $\mathrm{B}^{1+2} \mathrm{a}+\mathrm{b}$ への反転 を用いた鉗子挿入法を，また最近の話題としてP-260に よる $\mathrm{B}^{1+2} \mathrm{a}+\mathrm{b}$ への扦入法 , XBF-260F による気管内反転 法を紹介した 。

麻酔

患者の気管支鏡検査に対する印象は“ししんどい”であ
り，乥の原因の多くは検査中の咳嗽反射誘発である．し たがって気管支鏡検査前の麻酔は重要であり，十分な麻 酔で咳嗽反射を抑制することにより光の後の検査の成否 も決まる. 要点は喉頭蓋を越えて声帯に十分キシロカイ ンを噴霧することであり，我々は気管支鏡気管内挿入下 誘導ではなく，すでに以前可視範囲観察済みの患者に対 し麻酔台で直接気管内插管を実施する場合もある (Figure $1 \mathrm{~A}, 1 \mathrm{~B})$.

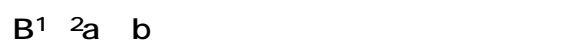

$\mathrm{B}^{1+2} \mathrm{a}+\mathrm{b}$ 一の鉗子挿入は観察自体も困難であるだけ でなく，鉗子孔が右から出るため通常の挿入法では左側
1財団法人太田綜合病院附属太田西ノ内病院呼吸器センター外 科.

別刷請求先: 高橋博人, 財団法人太田綜合病院附属太田西ノ内病 院呼吸器センター外科, = 963-8558 郡山市西ノ内 2-5-20.

1Department of Thoracic Surgery, Ohta Nishinouchi Hospital,
Japan.

Reprints: Hiroto Takahashi, Department of Thoracic Surgery, Ohta Nishinouchi Hospital, 2-5-20 Nishinouchi, Kooriyama, Fukushima 963-8558, J apan.

(C) 2005 The J apan Lung Cancer Society 


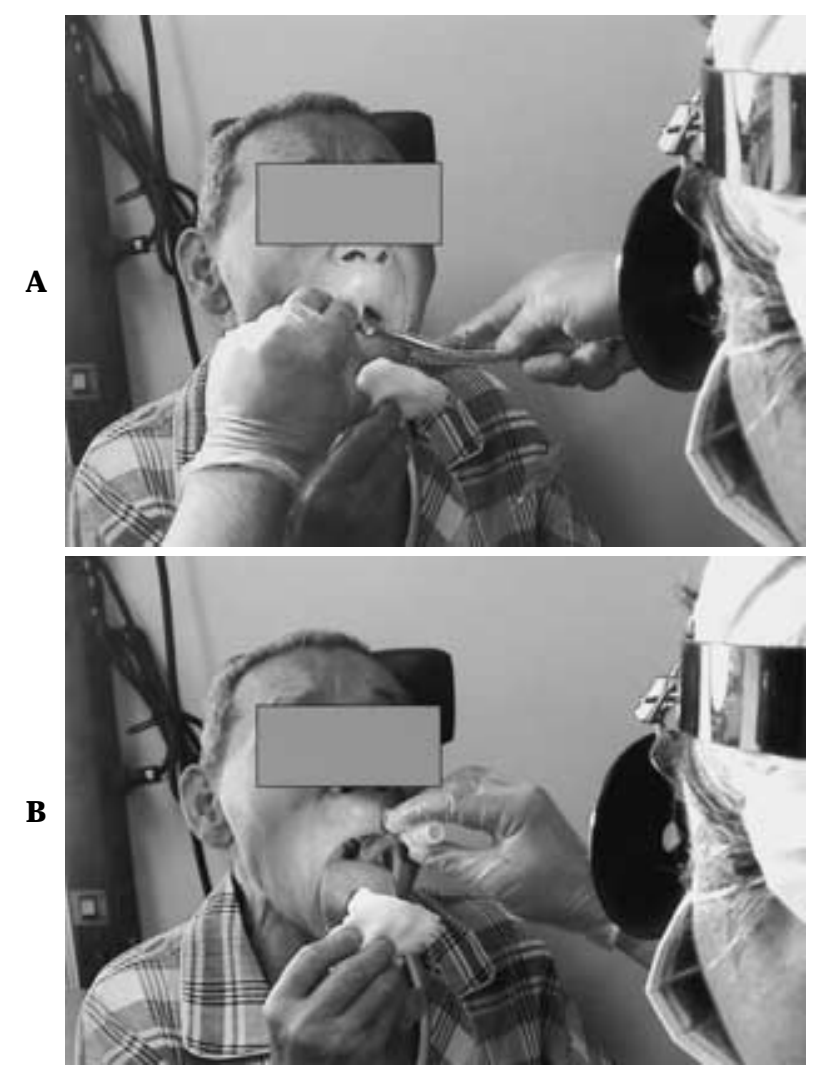

Figure 1. A, B: Intubation after local anesthesia.

に位置する $\mathrm{B}^{1+2} \mathrm{a}+\mathrm{b}$ はさらに遠くなり挿入困難であ る．したがって我々は気管支鏡先端を舌区支に挿入した 後気管支鏡を 180 度回転させ , down 操作で上区支へ進 め, $\mathrm{B}^{1+2} \mathrm{a}+\mathrm{b}$ に鉗子を挿入している.

P- 260

また最近の話題としてP-260による $\mathrm{B}^{1+2} \mathrm{a}+\mathrm{b}$ への挿 入法,XBF-260F による気管内反転観察を紹介した P-260 は外径が約 $5 \mathrm{~mm}$ であり，末梢気道への挿入性が向上し $\mathrm{B}^{1+2} \mathrm{a}+\mathrm{b}$ 一反転を要せず直接挿入可能であり，鉗子挿入 が容易となった反面，ハイブリッドであるため画質が落 ち, 末梢擦過時に腰が弱く押し戻され易い等の欠点はあ る.

\section{$X B F-260 F$}

XBF-260F は外径 $2.8 \mathrm{~mm}$ と細径化を実現し, 胸膜直下 近傍の末梢病変まで観察, 生検を可能にし, バーチャル ブロンコグラフィーとの併用で注目されている . 我々は 同時に本機種の先端部旋回半径が格段に小さくなってい ることに気付き，気管内反転法を開発した．気管狭窄部 を越えて細径スコープを進め，右主幹で先端部を反転さ せ気管まで引き戻し病変を末梢側より観察することによ り，バーチャルブロンコグラフィーでは観察し得ない狭 窄部末梢の細部構造を観察し得，今後有用な観察手技に なり得ると考える (Figure 2$)$ ）.

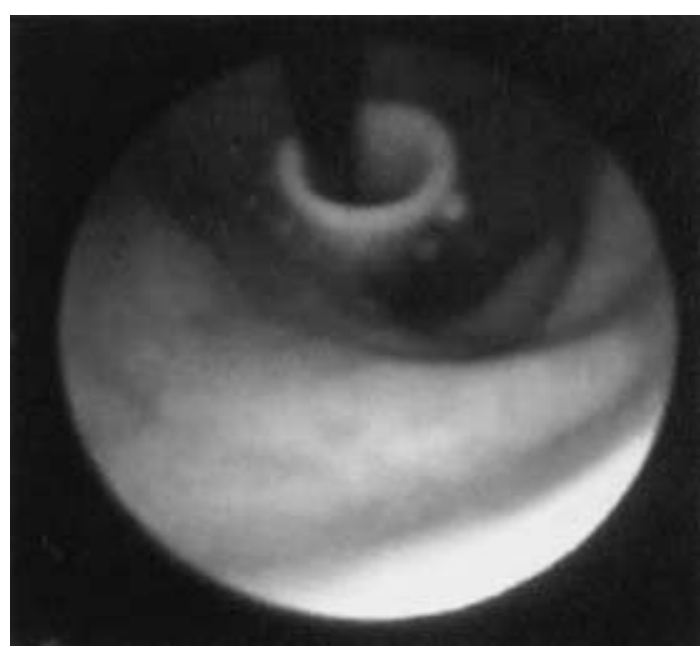

Figure 2. Bronchoscopic observation by inversion technique.

呼吸器疾患に対する超音波の応用

はじめに

超音波診断は卓越した局所分解能を持ち，また血流等 の機能診断が可能である.我々は肺癌等の呼吸器疾患の 補助診断法として積極的に応用してきたので, 経気管超 音波内視鏡 (trans-tracheal endoscopic ultrasonography: TUS)，経食道超音波内視鏡下穿刺吸引法 (transesophageal endoscopic ultrasonography guided fine needle aspiration biopsy: EUS-FNAB)，体表超音波検査，術中 超音波検査を中心に報告する .

TUS

使用機種は超音波観測装置 EU-M30 及び細径プローブ XUM-B20-26R (20 MHz) である. 現在進行中のstudy は，1) 胸部 X 線無所見肺癌 (occult) の深達度診断，2) 肺癌の縦隔肺門リンパ節転移診断，3) 末梢肺野病変の 質的診断，4) 気道中枢病変の進展状況，5）縦隔腫瘍の 質的診断である! ${ }^{1-6}$

Occult の深達度診断

Occult の治療方針決定において TUS の癌深達度診断 は有用である.気管支層構造は 5 層で，軟骨が第 $3 ， 4$ ， 5 層と良好に描出された.TUS で 26 病変の深達度を判断 し，A 群：軟骨内浸潤，B 群：軟骨または軟骨外浸潤の 2 群に分類した.TUS の深達度診断と治療効果または病 理診断が一致したのは, 26 病変中 22 病変で, 不一致が 4 病変であった . .,8

新規開発状況

1)一体型TUS，2) TUS ガイド下経気管支穿刺吸引細 胞診，3) 3D-TUS(Figure 3)，4) 電子スキャン内蔵 TUS による中枢気道病変のカラードプラ血流表示 ${ }^{9}$ (F igure 


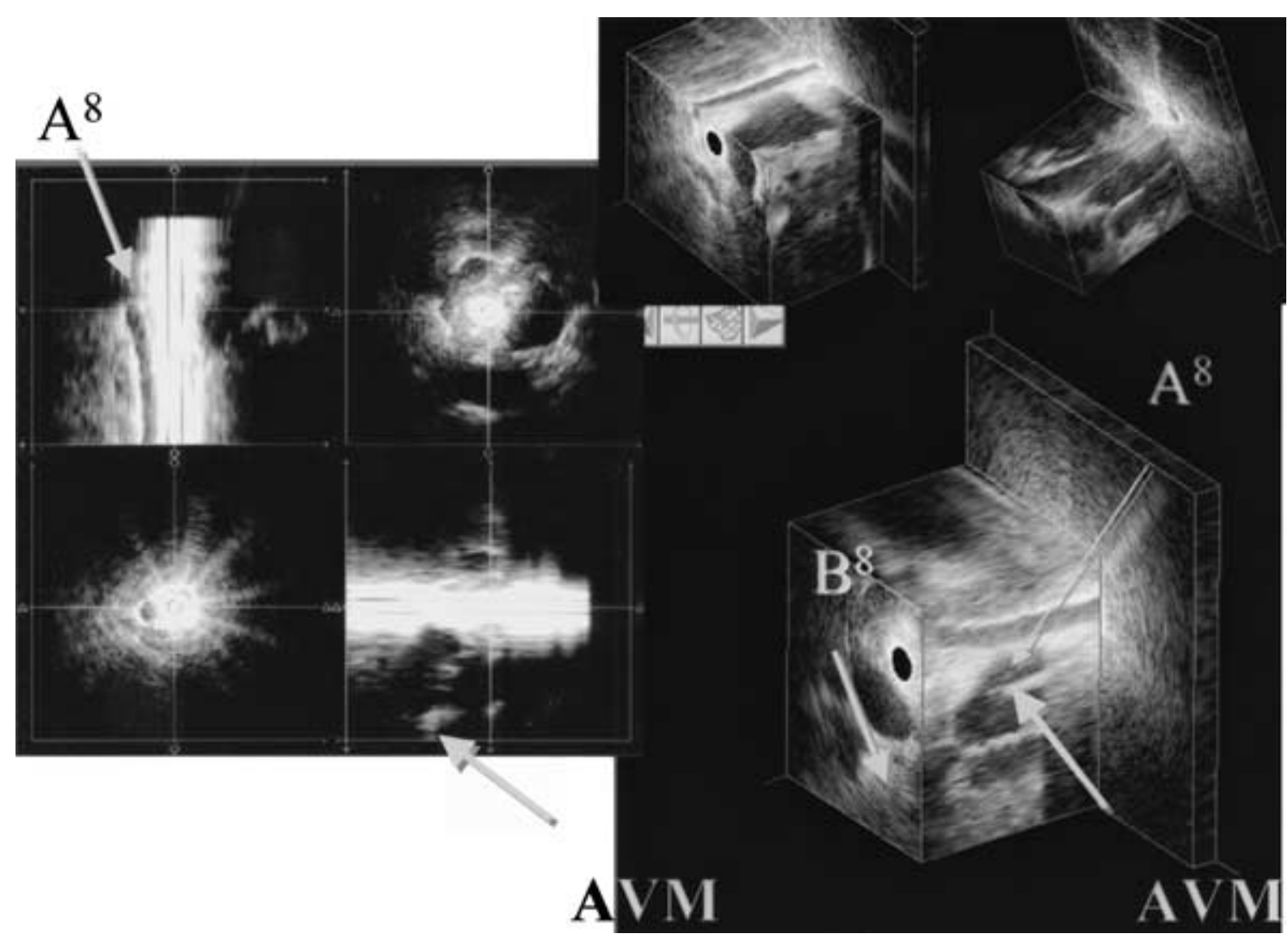

Figure 3. Using 3D-TUS, arteriovenous malformation ( $A V M)$ was observed transbronchially.
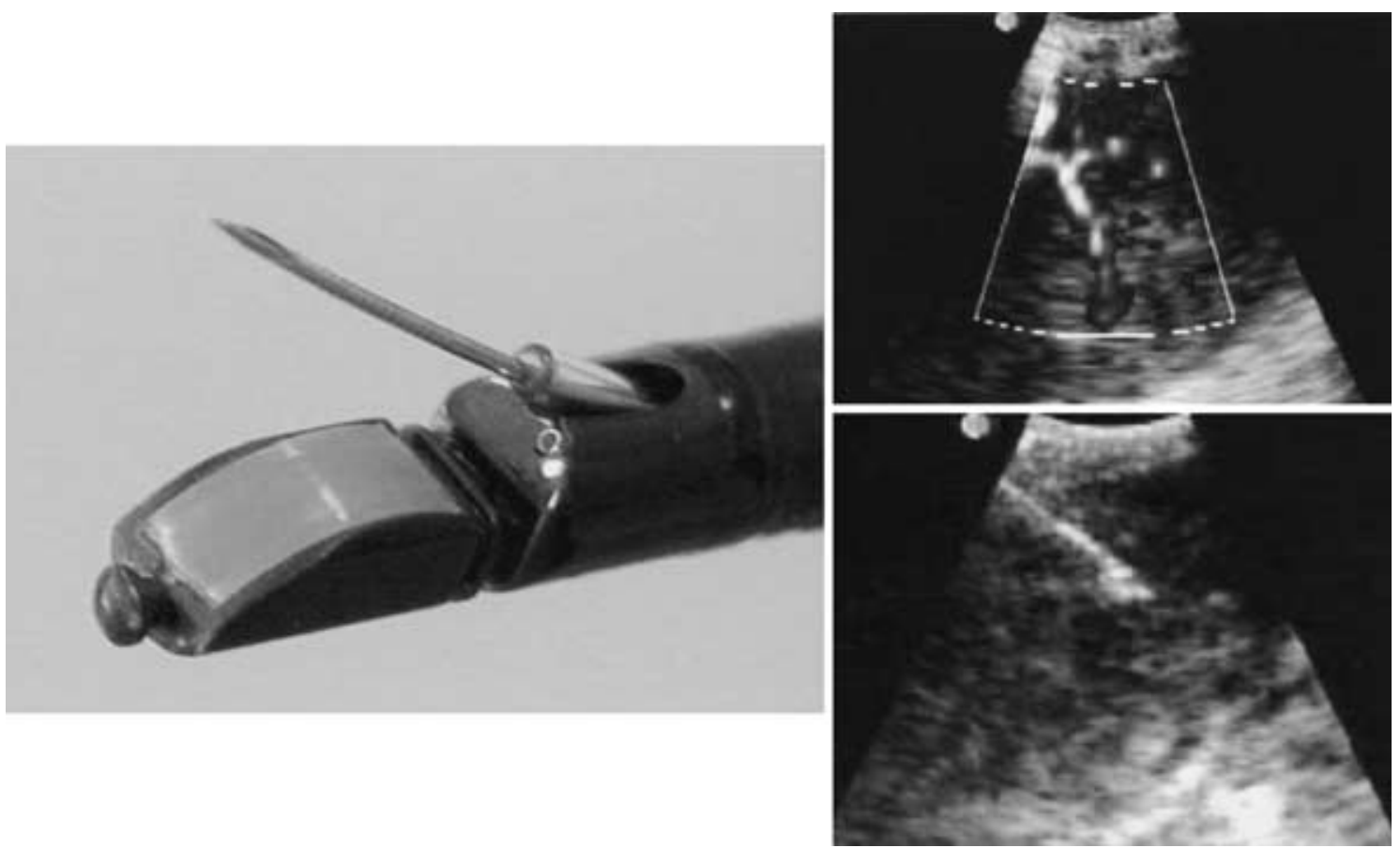

Figure 4. Convex scan ultrasonography: XBF-UC4OP can allow observation of tumor vessel flow and US guided aspiration cytology. 

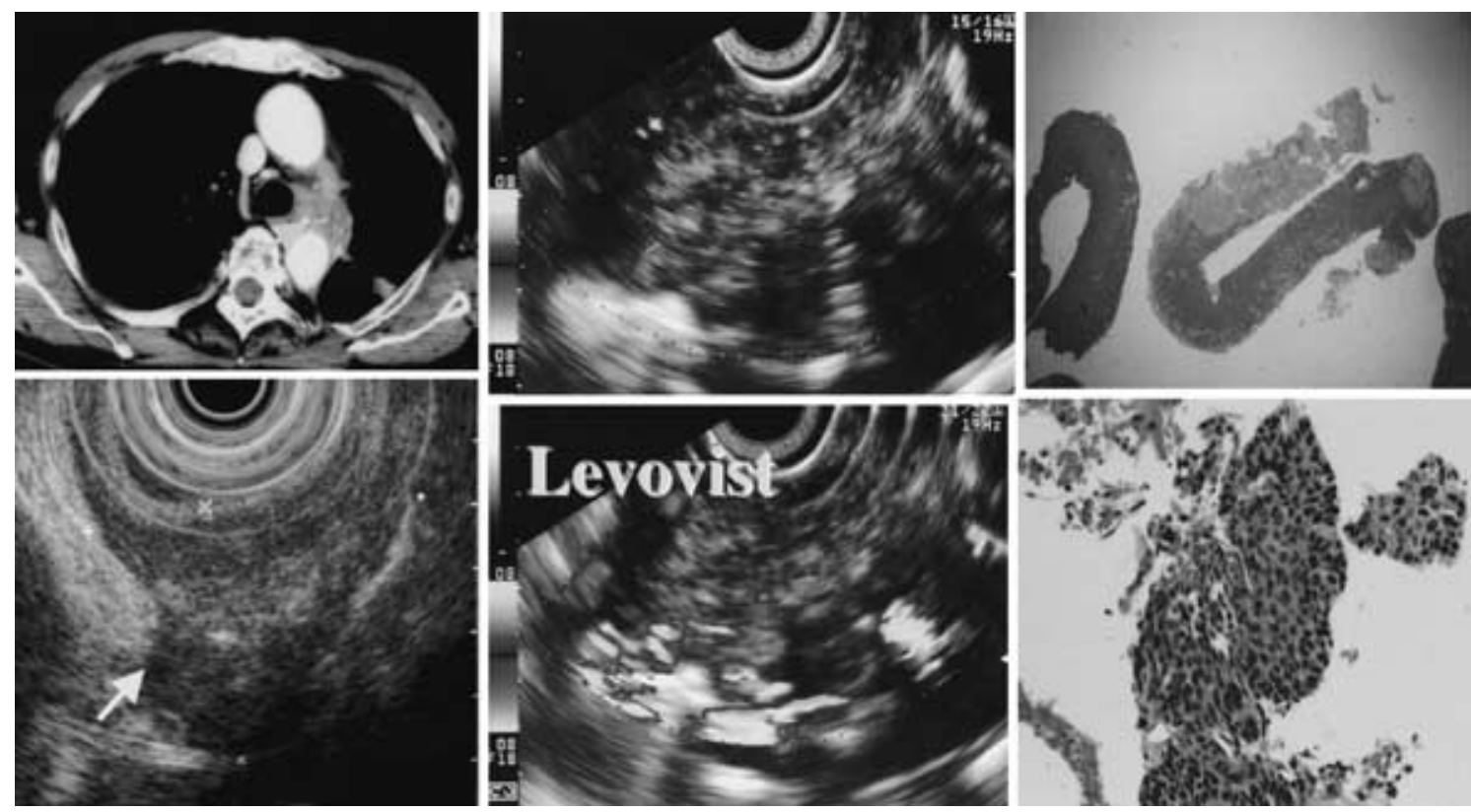

Figure 5. Endoscopic ultrasonography guided fine needle aspiration biopsy.

4)，5) 血管内超音波法 (intravascaler ultrasaound: IVUS) 用細径プローブとクロマフローを用いた末梢肺野 病変の血流表示，6) 末梢ブラシ擦過時においてガイド ワイヤー誘導型 TUS で病変到達を確認する TUS-guided lung cytology 法等である.

\section{EUS-FNAB}

肺癌やリンパ節においても食道に近接する場合 ,EUSFNAB が可能である .

方法

使用機種は GF-UC30P で，SSD-5000 に接続し経食道的 に観察，穿刺した .

結果

EUS-FNAB は腫瘍，リンパ節を観察しつつ，周囲に血 管がある場合にも安全に穿刺し得 組織診も可能である. 腫瘍内部の血流をカラー表示し得, Levovist 静注により リンパ節内血流も増強された (Figure 5) .

謝辞 : 発表の機会をいただいた森谷浩史先生に感謝申し上げ ます．

\section{REFERE NCE S}

1. 羽根田吉司 . 超音波断層法による縦隔腫瘍診断, 特に経
気管超音波断層法に関する研究 . 抗研誌 . 1968;20:202220.

2. 高橋博人, 車川寿一, 磯上勝彦, 他 . 経気管支超音波内視 鏡にて縰隔リンパ節を観察し得たサルコイドーシスの 1 例．気管支学．1994;16:597.

3. 佐川元保, 高橋博人, 栗本典昭, 他. 人見滋樹. 監修. 気 管支鏡による超音波検査．京都：金芳堂；1999:1-77。

4. 高橋博人, 佐川元保, 佐藤雅美, 他 . 細径プローブを用い た経気管気管支超音波内視鏡の気管支内外病变診断応用 への試み、気管支学 . 1997;19:189-194.

5 . 高橋博人, 佐川元保, 佐藤雅美, 他. 経気管気管支超音波 内視鏡(TUS)による末梢性肺野病変の観察.日呼吸会誌 . 1998;36:857-863.

6 . 佐川元保,高橋博人, 佐藤雅美, 他. 経気管気管支超音波 内視鏡 (TUS) による肺門・縦隔リンパ節腫大の評価 . 日 呼吸会誌 . 1998;36:509-512.

7 . 高橋博人, 須田秀一, 山中秀樹, 他 . 経気管超音波内視鏡 (TUS) による胸部 X 線無所見肺癌の深達度診断一PDT の適応判断を中心に . 気管支学 . 2002;24:618-622.

8. Takahashi H, Sagawa $M$, Sato $M$, et al. A prospective evaluation of transbronchial ultrasonography for assessment of depth of invasion in early bronchogenic squamous cell carcinoma. Lung Cancer. 2003;42:43-49.

9 . 高橋博人, 新井川弘道, 半田政志, 他. 超小型電子スキャ ンを用いた経気管超音波内視鏡 (TUS) による血流表示法 の開発.気管支学 . 2002;24:288-294. 